\title{
LA REINTERPRETACIÓN DEL TEXTO EN LA PANTALLA: NAZARÍN DE BENITO PÉREZ GALDÓS EN EL IMAGINARIO DE LUIS BUÑUEL
}

\section{The Reinterpretation of the Text on the Screen: Nazarin by Benito Pérez Galdós in the Imagery of Luis Buñuel}

\author{
JUAN Agustín MANCEBO RoCA \\ Universidad de Castilla-La Mancha \\ Juan.Mancebo@uclm.es \\ ORCID ID: 0000-0003-4942-8879
}

Recibido: 08-08-2021 / Aceptado: 10-09-2021

DOI: https://doi.org/10.51743/cilh.vi47.230

RESUMEN Este trabajo analiza la influencia del imaginario galdosiano en Buñuel a través de la adaptación de Nazarín así como su predominio en otras películas del director en la época mexicana. A través de una revisión bibliográfica, hemerográfica y audiovisual, planteamos los nexos y variaciones sobre el argumento original concluyendo que el escritor canario no solo es fundamental en el universo cinematográfico sino también en la filosofía última del director aragonés.

PALABRAS CLAVE: adaptación; cine; literatura; cristianismo; poesía.

ABSTRACT

This work analyzes the influence of Galdós's imaginary on Buñuel through the adaptation of Nazarin as well as its predominance in other films by the director, from the Mexican period. We propose the links and variations that Buñuel made on the original plot through a bibliographic, hemerographic, and audiovisual review, concluding that the writer is not only fundamental in the audiovisual universe but also in the ultimate philosophy of the Aragonese director.

KEY WORDS: Adaptation; Cinema; Literature; Christianity; Poetry. 


\title{
LA REINTERPRETACIÓN DEL TEXTO EN LA PANTALLA: NAZARÍN DE BENITO PÉREZ GALDÓS EN EL IMAGINARIO DE LUIS BUÑUEL ${ }^{1}$
}

\author{
Juan Agustín Mancebo Roca \\ Universidad de Castilla-La Mancha
}

\section{INTRODUCCIÓN}

Es la única influencia que yo reconocería, la de Galdós, así en general sobre mí. Luis Buñuel

Lo más admirable de lo fantástico es que lo fantástico no existe, todo es real.

André Bretón

SE HA ESCRITO FRECUENTEMENTE sobre el carácter azaroso de algunas películas mexicanas de Luis Buñuel ligadas a su idiosincrasia vital y creativa en el juego de despiste perpetuo y dobles sentidos que

${ }^{1}$ El autor quisiera agradecer a las profesoras Mónica Vázquez Astorga (Universidad de Zaragoza) y Elena de Ortueta Hilberath (Universidad de Extremadura) su inestimable ayuda para localizar parte de la documentación de este trabajo. Del mismo modo, desea hacer constar su reconocimiento a Julio Martín Sánchez (UNED), Mónica Sánchez Tierraseca, Antonio José de Llano y José Ángel Sánchez Gil (UCLM) por sus aportaciones y sugerencias. 
tanto gustaba al calandino. En cierto sentido, la fortuna crítica de filmes como Los olvidados (1950) y Nazarín (1958) tuvo más que ver con su repercusión europea que con la recepción mexicana que fue enormemente crítica con las propuestas del aragonés. Ambos filmes devolvieron al autor a su primigenio prestigio vanguardista devaluado en el intersticio nómada que fue desde su condición de enfant terrible del surrealismo hasta las producciones comerciales de la primera época mexicana.

Los olvidados compuso el primer gran ensayo en la rentrée cinematográfica de Buñuel que reafirmaba una mirada revolucionaria de matriz surrealista ligada a la crítica social que había compuesto en Las Hurdes. Tierra sin pan (1933) y que Carlos Fuentes definió como «una terrible mirada arrojada [...] sobre los horrores de la vida rural, ignorante, incestuosa y brutal» [1992: 555], palabras que podrían concretar el espíritu de Los olvidados. Al igual que había sucedido con el gobierno español, que prohibió Las Hurdes por denigrar la imagen de una región que permanecía anclada en el medioevo, Los olvidados tuvo un rechazo similar puesto que mostraba las heridas y señalaba el monstruo en el que se había convertido México amplificando la fractura social entre los favorecidos y los desheredados. Filmar los arrabales de Ciudad de México constituía «un despiadado cuerpo a cuerpo con la realidad» [Paz, 2012: 36] y su exhibición enervó a la sociedad bienpensante y al mundo del cine. El director recordaría las reacciones violentas que provocó: se le consideró un gachupín indeseable, se pidió su expulsión del país e incluso fue amenazado por Jorge Negrete, protagonista de Gran Casino (1946). La lúcida mirada oblicua del aragonés no solo trasladaba a la pantalla a los parias de México, sino que abofeteaba a toda una industria cinematográfica y a una sociedad ensimismada mediante una película que chocaba con el desarrollismo tecnológico oficializado [Fuentes, 1993: 57]. Hasta ese momento, como ha especificado Carlos Monsiváis, el 
cine mexicano había construido un imaginario que reflejaba los anhelos y sueños del público al que estaban dirigidas.

El caso de Nazarín, pese a ofrecer paralelismos con la producción de Oscar Dancingers, fue aun más complejo puesto que ocho años después del estreno de Los olvidados, la cinematografía azteca seguía observando con desconfianza el trabajo de un cineasta que afirmaba su libertad dentro de un modelo agotado que no escapaba de un sempiterno ensimismamiento. En este caso, fueron Octavio Paz y John Huston los que tuvieron la generosa capacidad de dar luz a una película que quería ser silenciada por los grupos de poder. Cuando la industria envió al Festival de Cannes La cucaracha (Ismael Rodríguez, 1958), Paz y Huston consiguieron una invitación directa del Festival para Manuel Barbachano Ponce y Nazarín obtendría el Premio Especial del Jurado. Ambos reivindicaron la maestría de un filme que entendía el cine como un vehículo capaz de manifestar la problemática humana en toda su dimensión espiritual, como instrumento de la poesía.

Que Nazarín sea una de las obras emblemáticas de la historia del cine, así como un producto cultural de primera magnitud queda fuera de toda duda. Del mismo modo, esa consideración eliminaba cualquier precepto azaroso sobre la concepción del filme puesto que hablamos de la coincidencia de tres creadores superlativos, el fotógrafo Manuel Álvarez Bravo, el cinefotógrafo Gabriel Figueroa y el propio Buñuel, capaces de reconfigurar el complejo mundo de Benito Pérez Galdós. Por otra parte, no podemos olvidar el guion de Julio Alejandro que, junto a Buñuel, redactó varias versiones del libreto en las que pulió su trabajo sucesivamente [Martínez Herranz, 2020: 99] así como los arreglos en los diálogos de Emilio Carballido.

En este sentido, Nazarín sintetizaba tiempos y espacios muy diversos: la España finisecular y el México del porfiriato que representaban dos concepciones antagónicas y a la vez complementarias de lo hispánico. Pese a que Buñuel se refería a un país que no era México 
ni España sino a un lugar que mostraba en la pantalla, Nazarín era una producción mexicana profundamente imbuida del espíritu galdosaiano a través de la mirada rebelde de Buñuel, el soporte emocional de Figueroa y todo ello inmortalizado en las instantáneas de Álvarez Bravo.

La dualidad de contrarios se trasladaría al reparto. Francisco Rabal renunció al sueño norteamericano para interpretar al padre Nazario dado que su físico cumplía con los rasgos árabes del libro [Jones, 2018: 55], colaboración que devendría en una complicidad personal y profesional que duraría el resto de sus vidas: «me agrada el hombre y me agrada el actor que me llama "tío" y al que yo llamo "sobrino"" [Buñuel, 1998: 285]. Como explicitaba Jean-Claude Carrière, Rabal componía con Fernando Rey los dos alter ego de Buñuel: el primero reflejaba lo popular y el segundo lo aristocrático [Tras Nazarín, 2015: 50m40s]. A Rabal se le unieron actores mexicanos como Rita Macedo -que había trabajado con el aragonés en Ensayo de crimen (1955)Marga López, Ignacio López Tarso, Pilar Pellicer y Jesús Fernández, limpiabotas reconvertido en actor que tendría un secundario en $\mathrm{Si}$ món del desierto (1965), configurando un plantel que pergeñaba la ambición de una película a priori intrascendente.

\section{MARCO TEÓRICO, ANTECEDENTES Y METODOLOGÍA}

Para la elaboración de este artículo se han tomado como referentes las novelas de Benito Pérez Galdós relacionadas con el universo del calandino: La desheredada (2018), Halma (2016), Nazarín (2016), Tristana (2004) y parte de las Obras completas editadas por Aguilar (2003). Para ubicar a Galdós en el contexto euroamericano se ha utilizado el manual de Bravo Castillo [2010].

En cuanto a las influencias galdosianas en Buñuel, se han tomado como base los ensayos de Arantxa Aguirre [2020 y 2008]. En cuanto 
literatura de Galdós y el cine del Buñuel se han utilizado las monografías de John Sinnigen [2008] que estudia el caso del cine mexicano y Ramón Navarrete [2003] que hace lo propio con el español. Antonio Monegal [1993] y Víctor Fuentes [1986] han incidido en la relación de la literatura en el cine del aragonés. Manuel López Villegas [1998] ha focalizado su trabajo en la influencia sadiana en Buñuel y Agustín Sánchez Vidal [1982] recuperó los textos literarios del director.

Sobre Luis Buñuel se han utilizado las monografías de Manuel Hidalgo [2019], Julie Jones [2018], Jean-Claude Carrière [2011], Ian Gibson [2008], Agustín Sánchez Vidal [2009 y 2000], Carlos Barbachano [2000] y Víctor Fuentes [2000]; los catálogos de las exposiciones de Enrique Camacho, Javier Pérez y Manuel Rodríguez [2000] y Luis Gasca [1989]; los manuales canónicos de Tomás Pérez Turrent y José de la Colina [1993], Max Aub [1985] y, por supuesto, la autobiografía de Buñuel y Carrière [1982]. También se han revisado los volúmenes recientes que indagan en su correspondencia y archivos como los de Jo Evans y Breixo Viejo [2018] y Javier Herrera [2015] respectivamente.

En cuanto a la relación de Buñuel con México han resultado fundamentales los catálogos de Héctor Orozco [2019] sobre los stills de Manuel Álvarez Bravo en el rodaje de Nazarín, el de Banville, Lemagny y Fuentes [2008] sobre Álvarez Bravo, el de Carmen Peña Ardid y Víctor Lahuerta Guillén [2007] acerca de Los olvidados y el de Elías Levin [1996] sobre Figueroa, así como la monografía de Víctor Fuentes [1993]. En el ámbito literario son destacables los ensayos de Carlos Fuentes [2017] -inacabado-, Octavio Paz [2012] y Carlos Monsiváis [2006].

Sobre los audiovisuales se ha hecho una revisión de la filmografía de Luis Buñuel y de las películas relacionadas con el contexto fílmico, así como de los documentales de Javier Espada [2015], Javier Rioyo [1999] Gaizka Urresti y Javier Espada [2008] y a las películas de Javier Espada [2018] y Carlos Saura [2001]. 


\section{El UNIVERSO DE PÉREZ GALDÓS EN LA OBRA DE LUIS BUÑUEL}

La obra literaria de Benito Pérez Galdós fue conquistando a Buñuel a lo largo de su vida. El otrora violento vanguardista había desconfiado en su juventud del autor canario ya que su estajanovismo antiburgués despreciaba cualquier residuo cultural que le recordara el pasado cuando estaba influenciado por la obra de Charles Darwin: «me deslumbró y me hizo acabar de perder la fe» [Buñuel, 1998: 37] y la libertad sin ambages del Marqués de Sade: «tenía más de veinticinco años cuando lo leí por primera vez. Me causó una impresión mayor que la lectura de Darwin» [Buñuel, 1998: 255]. Además, Buñuel estuvo determinado por los "filósofos de la sospecha»: la duda de Dios (Nietzsche), del mundo (Marx) y del yo (Freud), pensadores que ponían en entredicho los pilares metafísicos [Aguirre, 2008].

Ese rechazo por la obra galdosiana era consecuencia de una generación que no reconocía su obra. Ramón Gómez de la Serna dijo sobre Galdós: «que todo lo garbanceó bastante» y Valle Inclán, a través de Dorio de Gadex, lo señalaba cuando proponía a Max Estrella al sillón de la Academia en Luces de Bohemia (1920): "precisamente ahora que está vacante el sillón de Don Benito Garbancero» [Aguirre, 2008].

La autoridad galdosiana en el cineasta se hizo mayor cuanto más involucionaba la influencia surrealista y más desencantado estuvo con la deriva científica del siglo XX cuya desconfianza y rechazo le llevaron a la relectura y al refugio sentimental del canario. El zeitgesit de Galdós estaba firmemente anclado en el siglo XIX, periodo histórico en el que Buñuel se reconocía o, al menos, le hubiera gustado reconocerse.

Por otra parte, Galdós se configuraba como el análisis revisionista de un modelo teológico, ya que la deriva técnica del siglo XX le hacia abrazar la inadmisible idea de la divinidad puesta en boca de uno de los personajes de La Vía Láctea (1969): «mi odio a la Ciencia y mi 
desprecio por la tecnología me acabarán conduciendo a esa absurda creencia en Dios» [Buñuel y Carrière, 1989: 390] como si el siglo XX fuera un epígono o un modelo constituido a partir del siglo XIX. Pérez Galdós retrotrae a Buñuel a un periodo histórico en el que el discurso metafísico ha entrado en crisis sin necesidad de los avances especializados que tanto le disgustaban y en el que localizaba coincidencias con la vanguardia: «Encontré en sus obras elementos que podríamos llamar «surrealistas»: amor loco, visiones delirantes, una realidad muy intensa con momentos de lirismo [Buñuel, 1999: 104].

El mundo galdosiano se convirtió en un referente para el calandino que lo empieza a leer con seriedad a los treinta años tras el rodaje de L'âge d'or (La edad de oro, 1930). En 1935 cuando regresó a España tuvo un contacto directo con su obra en su condición de productor asociado de Filmófono donde planearía la adaptación de Fortunata y Jacinta, Doña Perfecta y Ángel Guerra. La fijación galdosiana era, a la vez, la interrogación permanente por la posibilidad de haberse dedicado a la literatura abjurando del medio en el que terminó desenvolviéndose: «soy un novelista frustrado que terminó en director de cine $[. .$.$] Mi ideal hubiera sido encerrarme a escribir como un mon-$ je. Pero no tengo ningún talento» [Fuentes, 2017: 43].

En la madurez de Luis Buñuel, Nazarín y Tristana se transformarían en películas que condensan el universo literario de Pérez Galdós y las obsesiones del creador aragonés. De hecho, parte de la crítica ha reconocido que las adaptaciones son superiores a las novelas [Barbachano, 2000: 185]. La obra del escritor provocará numerosas intertextualidades en el universo cinematográfico del aragonés. Para Buñuel, Pérez Galdós suponía una manera de interrogarse sobre sus orígenes y su acervo cultural, además de ponerlo como ejemplo de la ignorancia de los españoles sobre su cultura. De hecho, en su reivindicación galdosiana existía el reconocimiento de un universo literario que perdía influencia al igual que sucedía en el lugar donde se gestaba: «es el poderío de un país lo que decide sobre los grandes escrito- 
res. Galdós es con frecuencia comparable a Dostoievski. Pero ¿quién le conoce fuera de España?» [Buñuel, 1998: 261].

En el reconocimiento de un creador en el otro, Galdós y Buñuel coincidieron durante tres años en Madrid, desde que Buñuel llegó a la Residencia de Estudiantes en 1917 hasta 1920, fecha en la que falleció el escritor. En Mi último suspiro Buñuel recordaba: «conocí incluso al gran Galdós [...] A decir verdad solo lo vi una vez, en su casa muy viejo y casi ciego, al lado del brasero, con una manta en las rodillas» [Buñuel, 1998: 67]. Jean-Claude Carriére mencionaba que Buñuel no hablaba demasiado de literatura y cuando lo hacía «se refería más bien a Sade, a Dostoievsky o a Pérez Galdós, a quien había conocido de muy viejo» [2011: 49]. Por otra parte, en su biblioteca hubo tres secciones principales: «Galdós, algunos surrealistas y precursores y los «Souvenirs Entomologiques» de Fabré» [Aranda, 1970: 226].

Por tanto, el referente de la obra de madurez del director aragonés y de parte de su filmografía mexicana fue el costumbrismo galdosiano. Como ha señalado Víctor Fuentes, se puede establecer un correlato entre los niños abandonados y los basureros de Los olvidados con las pandillas de desamparados de la ronda de Embajadores y el Barrio de las Peñuelas de La desheredada (1881). Del mismo modo, Fuentes afirmaba que la escena de la gallina de Los olvidados estaba presente en Fortunata $y$ Jacinta (1887). En la película el cuerpo de Pedro rodaba en un vertedero al igual que lo hacía el de Villamil en el basurero de Príncipe Pío en Miau (1888). También se encuentran otras asociaciones «mediante la técnica surrealista de «lo uno en lo otro» [Fuentes, 1993: 55] entre el grito de Paloma en El bruto [1953] y Doña perfecta (1876). Doña perfecta sería el primer proyecto frustrado de Buñuel en México por las reticencias de Dolores del Río para filmar con un director que no trabajaba desde hacía años [Carrière, 2011: 49].

Otros ecos de las obras de Pérez Galdós se presentan en Viridiana (1961) a partir de la lectura de Ángel Guerra (1891) y de Halma 
(1895), novela del ciclo espiritualista en la que aparecían los personajes de Nazarín, configurando una «recuperación de la tradición cultural española, amarga y esperanzada, crítica y heterodoxa, la tradición de Cervantes y la picaresca, de don Juan y san Juan, del cuerpo y del alma, como una manera de abrazar al marginado, al fuera de la ley» [Fuentes, 1992: 564].

En Tristana (1972) Buñuel desplegaba todos sus recursos de índole surrealista reconstruyendo el mundo emocional del escritor y cuyo resultado reconoce la simbiosis de los dos creadores ya que representaba un espacio autobiográfico que remitía a su juventud. Para Pérez Galdós porque estaba inspirada en su relación con la actriz Concha «Ruth» Morell y para Buñuel significaba recuperar los recuerdos de los espacios en los que había transitado su patafísica Orden de Toledo y volver a sí mismo en lo que habría sido su testamento cinematográfico: «Sí, yo soy Don Lope. Ha venido a ser mi historia. Muy liberal, muy anticlerical al principio, y, a la vez, a la vejez, sentado en una camilla tomando chocolate, iqué maravilla de chocolate! con tres curas. Y la nieve, afuera» [Aub, 1985: 146]. En Toledo la presencia de la pulsión de la muerte se enfatizaba en el reflejo de Tristana en el espejo de la putrefacción eterna del mármol de la escultura del cardenal Tavera.

\section{NAZARÍN, UNA ANTOLOGÍA DE LA CRUELDAD}

Publicada por Benito Pérez Galdós en su madurez, Nazarín (Impr. La Guirnalda, Madrid, 1895) se conformaba como una de las cuatro obras que publicó en esos dos años junto a Halma, Misericordia y El abuelo y que constituían la culminación de su giro espiritualista [Bravo Castillo, 2010: 889]. Nazarín relataba la vida y las desventuradas andanzas de «un árabe manchego, natural del mismísimo Miguelturra, y se llama don Nazario Zaharín o Zajarín» [Pérez Galdós, 2016: 
24] cuya máxima era seguir escrupulosamente los preceptos evangélicos, pero su obstinación le lleva a abandonar su ministerio y arrojarse a los caminos para encontrar el sentido cristiano a su existencia. En los arrabales y los pueblos colindantes a la capital sufre todo tipo de penalidades acompañado de sus «discípulas» o «las nazarinas» [Pérez Galdós, 2016: 243], la prostituta Ándara y la mística Beatriz. En la novela, la actitud de Nazarín combinaba éxitos con fracasos que en un delirio final produce una comunión con sus creencias.

Nazarín entrelazaba los preceptos del cristianismo -la pasión de Cristo y las vidas de los santos- con la tradición literaria española de la novela picaresca y cervantina, o para ser más precisos, seguía el legado de Jesucristo y de Don Quijote. Parte de la crítica ha señalado la pervivencia de Tolstoi en el ciclo espiritualista de novelas españolas contemporáneas, aunque Nazarín estuvo determinado por el influjo de la mística española. En palabras de Sinnigen, la novela parece: «condicionada por el pesimismo finisecular, el auge de la novela rusa y los momentos críticos que se viven en España y que culminan en la crisis de 1898» [2008: 189]. En cualquier caso, lo esencial del relato «es la densidad humana de Nazarín, su concepción de la caridad activa, lejos de cualquier visión contemplativa y estática» que se habría apreciado en doña Guillermina de Fortunata y Jacinta [Bravo Castillo, 2010: 891].

Nazarín destacaba por la densidad del relato y conformaría una adaptación cinematográfica sintética y compacta. La referencia a la mística española recalcaba la crueldad innata del ser humano con todo semejante cuya actitud le resulte ajena o subvierta las convenciones sociales establecidas. La crueldad, rasgo típicamente español, se trasladaba a un universo mucho más violento que lejos de perder intensidad en su trasvase se amplificaba hasta llegar a extremos insospechados.

Entre la novela de Galdós y la ideología de Buñuel existían infinidad de vínculos. Buñuel confesaba que Nazarín le interesaba por la 
actitud de los personajes, pero, sobre todo, por la crudeza de las imágenes que podía trasladar a su imaginario. Por otra parte, señalaba el cariño que tenía por el cura: «Nazarín es un hombre fuera de lo común y por el que siento gran afecto [...] es una novela de su última etapa y no de las más logradas, pero su historia y su personaje son apasionantes, o por lo menos a mi me sugerían muchas cosas, me inquietaban» [Buñuel, 1999: 103-104].

La ferocidad recreada por Galdós insertaba el espíritu y los rasgos de la cultura española a través de la recuperación de la obra de Goya y de Valle-Inclán, así como la relectura barroca del pintor José Gutiérrez Solana. En la novela hay una brutalidad que se deslizaba iconográficamente desde Valdés Leal en el Finis Gloria Mundi (1672) ubicado en el hospital de la Caridad de Sevilla. El cuadro, del que Diego Velázquez mantenía que era imposible verlo sin taparse la nariz, era una de las obras favoritas del aragonés, que afirmaba que la descomposición del cuerpo era más literal que en el mármol del cardenal Tavera. Era la transcripción de la idea de la putrefacción con la que había fantaseado con Federico García Lorca y Salvador Dalí en la Residencia de Estudiantes a través de la lúcida intuición de la visión oscense de los carnuzos de Pepín Bello: «era muy corriente encontrarse un burro muerto devorado por las moscas, que había sido abandonado por su propietario al lado del camino. [...] El tema de los carnuzos nos obsesionó especialmente a Luis y a mí» [Castillo y Sardá, 2007: 54].

Imagen de carne muerta que con tanto tino representarían Buñuel y Dalí en Un perro andaluz (1929) y La edad de oro "cuadro que parafrasearon mediante las carroñas de los obispos [...] sobre las rocas de la Costa Brava» [Sánchez Vidal, 2009: 83] en su lectura del imposible matrimonio entre la carne y el espíritu. Como ha subrayado Carlos Fuentes, el imaginario de la crueldad de Buñuel compone la gran aportación de lo hispánico al surrealismo bretoniano de índole racionalista y cartesiana. Su poderío iconográfico concretaba y resumían la herencia de su acervo cultural. 
El Nazarín español se transpeninsularizó en el Nazarín mexicano incorporando los escenarios y los personajes suburbiales de la capital de España, Carabanchel, Móstoles, Navalcarnero y Aldea del Fresno a los escenarios de la Ciudad de México y en los pueblos aledaños de Tetelcingo, Tlayacapan, Jonocatepec, Atlalahucan, Coyococ, Yecapixtla, Oaxtepec, Tepoztlán y Cuautla y los volcanes Popocatépetl y Iztaccíhuatl. El universo de Pérez Galdós se recreaba, según Arturo Ripstein, en un espacio y tiempos anteriores al propio Galdós.

Buñuel reconocía que el proyecto de Nazarín venía desde los tiempos de El gran calavera (1949) puesto que tenía los derechos de la novela y los de Doña Perfecta. El productor Pancho Cabrera le dijo que trabajara en esta mientras que él haría la adaptación de Nazarín, una novela que se podía situar en el México del porfiriato [Buñuel, 1999: 103] aunque se refería a las coordenadas espacio temporales de la adaptación como «si no es México ni España es un país posible el que muestro en la película [...] México es muy español. Lo es y no lo es, eso lo hace más interesante» [Turrent y De la Colina, 1999: 109].

Si la obra de Pérez Galdós está dividida en cinco partes, la estructura de la película se divide en dos, que posteriormente se subdividen en los capítulos del libro, por lo que la transcripción a la pantalla del libro es prácticamente literal. La primera parte de la novela se trasladada a la presentación cinematográfica del padre Nazario mostrándonos el lugar en el que vive, el modo en el que lo hace y las personas y circunstancias que le rodean. La segunda parte contempla la peregrinación de Nazarín y sus discípulas para encontrar el sentido y los valores e ideales del cristianismo original que se convertirán en una empresa destinada al más absoluto fracaso. La división entre las dos partes las configura la acción en la que Ándara, para evitar que la localicen, quema la casa del padre Nazario extendiéndose el incendio a toda la hacienda. 


\section{EL ESPACIO SIMBÓLICO DE NAZARÍN}

Los videogramas de los créditos iniciales de Vicente Rojo establecen una entrada simbólica a la historia a través del carácter popular de los grabados mexicanos -denominados maderas- que nos refieren a otros títulos de películas de la época entre las que destacarían las colaboraciones de Figueroa y Emilio «Indio» Fernández con el pintor y grabador Leopoldo Méndez -Río Escondido (1947), Pueblerina (1948) y Un día de vida (1950)- que se transforman en una fotografía animada reivindicando su atribución artesanal. Los grabados son ilustraciones de los espacios emblemáticos de la ciudad de México, entre los que destacan las imágenes de la catedral y la plaza el Zócalo. Como ha puntualizado John Sinnigen, la plaza de la constitución es «el lugar emblemático de la imposición imperial de una cultura metropolitana sobre otra indígena [...]. El mestizaje de la Catedral también señala el carácter intercultural de este filme, basado en una novela española, escrito por dos españoles, dirigido por un español» [2008: 207].

De lo global se pasa a lo particular y la fotografía dinámica se traslada al patio del Mesón de los Héroes, humilde lugar de encuentro en el que vive el padre Nazario. Quisiéramos incidir en el sonido inicial del universo acústico de la Ciudad de México a través de los acordes de la flauta de pan que anuncia "tamales calientitos» [sic.] y que, al igual que el referente plástico introduce la acción. En este caso, Buñuel cita un elemento común tanto a México como a España, ya que la flauta de pan es un instrumento de uso popular ente los afiladores españoles.

El relato se traslada a la representación del sacerdote que subraya su aislamiento. De hecho, esa separación del mundo se enfatiza a través de la ventana que actúa como puerta, un muro simbólico que tienen que atravesar para poder penetrar en el mundo particular del santón. 
Buñuel hace una síntesis de la introducción de la novela para agilizar la narración. Evidentemente, el cine y la literatura son dos lenguajes distintos que el aragonés enlaza cuando los caballeros de la novela le inquieren sobre su condición: - «Su vida de usted, y no se ofenda, paréceme muy precaria. -Bastante; pero mi conformidad le quita toda amargura. En absoluto me falta la ambición de bienestar. El día que tengo qué comer, como; y el día que no tengo qué comer, no como» [Pérez Galdós, 2016: 30]. Si hay una división metafórica entre el mundo de los hombres y de Nazarín, la filmación lo resalta a través de la imagen de Cristo que se convierte en el espejo simbólico del ideario del sacerdote y en el que el cineasta traslada las palabras sobre su santidad de la Chanfaina: «¿Para qué sirve un santo? Para nada de Dios [...] ¿ ¿para qué sirve un santo más que para divertir a los chiquillos de las calles?» [Pérez Galdós, 2016: 43].

Ese espacio idílico del sacerdote sufre la primera alteración cuando es reprendido por tres prostitutas tras escuchar la acusación del padre de que ha sido la prima de una de ellas la que le ha robado. Esta escena remite al carácter español de la novela ya que sería literalmente imposible que tres mujeres -y mucho menos tres prostitutas- faltaran al respeto a un sacerdote en el México del porfiriato como reconocía el propio Buñuel.

Hay que reseñar los espacios de la crueldad en el inicio de la narración. Beatriz, enamorada de un hombre que la maltrata, intenta infructuosamente suicidarse. Ándara, tras insultar al padre, se pelea por unos botones robados con La Camella. Beatriz, tiene un delirio que en la novela «no es ni brujería ni demonios; es una enfermedad muy común y muy bien estudiada, que se llama histerismo» [Pérez Galdós, 2016: 122] en la que imagina que domina sexualmente a Pinto, mordiéndole el labio causándole un corte cuya sangre supone el augurio premonitorio de la violencia. 


\section{UNA HERIDA QUE LO CORROMPE TODO}

La segunda parte la configura la estancia de Ándara en la habitación de Nazarín. Tras la pelea con La Camella, Ándara pide refugio y se esconde malherida en la habitación del padre Nazario que la ayuda a reponerse de sus heridas e intenta convencerla de que vaya por el camino correcto. Su presencia, reseñada al principio de la película cuando uno de los personajes del patio se refiere a su olor corporal, inunda toda la habitación del cura, como si simbólicamente el mal que muestra la herida de Ándara infectara toda la estancia. Además, en ese momento, se producen dos imágenes esenciales de la película. La primera, el Cristo que se ríe a carcajadas en el delirio de Ándara, una "ocurrencia surrealista» a la que sigue otra no menos trascendental: la de Ándara que bebe de la palangana llena de su propia sangre. La visión mística, pese a que Buñuel se jacte de que es suya, tiene antecedentes en dos obras de Pérez Galdós como ha señalado Arantxa Aguirre. En La sombra (1870) escribe Galdós: «Me pareció que el Cristo estiraba los brazos y el cuello, desperezándose con expresión de supremo fastidio» [Pérez Galdós, 1890: 20] y, en El doctor Centeno (1883), el hambriento Felipín Centeno tiene una visión:

se le alegró el alma de tal modo, que no sabía por donde empezar, y esto le parecía bien, aquello mejor y todo venido del Cielo. Absorbido como estaba su ser enteramente por tan principal función, aún podía distraer el sentido de la vista para echar una mirada al Santísimo Crucifijo, que ya, sin saber cómo, tenía rostro de contento [Pérez Galdós, 1883: 32].

Cuando el olor descubre a Ándara, Beatriz le propone que limpie la habitación para que el cura no se vea implicado. Ándara opta por una solución más radical, quemar la estancia. Construye una pira con los escasos elementos del habitáculo en los que Buñuel aún se permite jugar con las iconografías cristianas que condenan al santo a las llamas pero salvan al niño Jesús. En este caso, el fuego tiene un carácter 
purificador, que trasladan las palabras de Ándara: «El aire malo se lava con fuego, sí» [Pérez Galdós, 2016: 77].

El incendio tendrá consecuencias funestas para Nazarín que se ve obligado a dejar su magisterio y a renunciar a sus escasos beneficios y el manto protector de la Iglesia que, pese a la rectitud moral del sacerdote, tampoco lo defenderá más. Antes de su partida, hay una especie de epílogo, ya que Nazario aparece en la casa de un cura que le reprende por su actitud indecorosa y le pide que la abandone discretamente ya que hay que proteger a la Iglesia de su escandalosa la actitud, pero antes le conmina amablemente a terminar su taza de chocolate. La escena enlaza simbólicamente con la futura de Tristana en la que Don Lope termina tomando chocolate con los curas pese haber abjurado de ellos. Nazarín muestra la hipocresía de los ministros de la Iglesia: el cura que lo expulsa y la del sacerdote que no defenderá a los oprimidos acusando al peregrino de herejía por defender las pautas cristianas.

\section{EL FRACASO DE LOS PRECEPTOS CRISTIANOS}

El peregrinaje de Nazarín corresponde a la tercera parte de la novela en la que encontrará todas las adversidades pese a las expectativas con las que inicia su partida [Pérez Galdós, 2016: 97]. En esta parte se reconoce una de las grandes divergencias entre la novela y la película. Mientras en la novela los fracasos se combinan con algún éxito, la película es una concatenación de desagracias, el «criminal en la virtud» pergeñado en la obra de Sade. En las asociaciones que se han hecho con El Quijote, Buñuel siempre defendió la diferencia fundamental entre ambos: mientras Don Quijote está a veces sano y a veces perturbado, el padre Nazario está siempre cuerdo [Turrent y De la Colina, 1999: 107].

En el deambular del padre está inscrito el fracaso. Como señala la novela «no huía de las penalidades, sino que iba en busca de ellas; no huía 
del malestar y la pobreza, sino que tras de la miseria y de los trabajos más rudos caminaba» [Pérez Galdós, 2016: 98]. Y la primera catástrofe acontece cuando pide limosna y el capataz le invita a trabajar a cambio de comida. Cuando el resto de los trabajadores se percatan, le espetan a Nazarín que se vaya. Los trabajadores y el capataz discuten, por lo que la actitud mendicante del padre ha provocado un conflicto entre el patrono y los trabajadores. Mientras Nazarín camina se escuchan disparos por lo que la primera acción del sacerdote ha terminado probablemente con heridos graves o alguien muerto.

Será en el siguiente pueblo cuando Nazarín se encuentre con Beatriz y Ándara, que lo reclaman en su condición de santo para que sane a una niña enferma. Nazarín se opone, pero finalmente accede a prestar atención a la muchacha. De nuevo, Buñuel compone una escena en la que el grupo de mujeres está preso de la superchería y el fanatismo recreando la histeria en la que resaltaba las trampas de la fe. Beatriz y Ándara: «Marta y María o, como escribe Octavio Paz, mezcla de Sancho Panza y María Magdalena; en todo caso, el caballero andante y sus escuderos. Virgilio y Sancho Panza son los guías del vidente ciego, cegado cuando abandona el claustro y sale al mundo» [Fuentes, 2017: 114].

\section{LA EPIDEMIA DE PESTE Y EL RECHAZO DE DIOS}

La progresión en el fracaso de Nazarín llega a su cénit en una de las más bellas y terribles escenas del filme. Lejos de tener los medios para rodar de manera solvente una epidemia de peste, Buñuel tuvo que ingeniárselas para hablar de la misma en Jonocatepec y Tlayacapan. La síntesis de la imagen de la niña arrastrando la tela blanca en contraste con otra sábana mecida por el viento reflejaba el carácter definitivo de la enfermedad en la que representa el horror en la blancura de la cobija y el desamparo de la niña que llora: 
Esa imagen resume la peste -mantenía Buñuel-. Una escena así no puede ser prevista en el guion. Estoy filmando una calleja solitaria, casi en ruinas. De pronto, surge en mi mente una imagen: una niña que avanza arrastrando una sábana. Tengo así una imagen irracional, pero que resume la tragedia [...] Cuidé, eso sí, de que la sábana se viera muy extendida, muy larga [Turrent y De la Colina, 1999: 109].

Esta atribución nos remite al carácter del director al que le gusta inventar anécdotas y restarse importancia puesto que en el guion original recogía la escena: «Una calle solitaria. En un balcón de primer término una sábana puesta a secar azota los barrotes del mismo con un chasquido crispante, debido a las ráfagas de aire que se han levantado. Por el centro de la calle avanza sola llorando, una niña de tres años» [Tras Nazarín, 2015: 39m10s].

Gabriel Figueroa Flores recordaba que la escena era poco alentadora ya que había sido Manuel Álvarez Bravo quien había provocado el llanto de la chiquilla. Además de las imágenes captadas por Figueroa, hay que destacar los stills de Álvarez Bravo que condensan y amplifican la imagen cinematográfica que, en su absoluto vacío metafísico, es eterna.

Este capítulo constatará que Nazarín está completamente vencido. Aun expulsado de la Iglesia desea impartir su ministerio a una mujer agonizante que lo rechaza llevando a sus labios el nombre del amado: «iNo Cielo!, iJuan!» [Alejandro y Buñuel, 1989: 95] Buñuel inserta fragmentos del Diálogo entre un sacerdote y una moribunda de Sade (1782) y la muchacha a la que intenta auxiliar rehúsa cualquier veleidad metafísica reivindicando el amor que los enamorados sellan con un beso, un acto supremo que no teme al contagio: «es el amor total y a pesar de todo. Un amor que ni siquiera cuenta con la esperanza» [Turrent y De la Colina, 1999: 109]. El sacerdote fracasa absolutamente incapaz de salvar el alma de la muchacha e insta a sus escuderas proseguir su camino: «Aquí ya no tenemos nada que hacer» [Alejandro y Buñuel, 1989: 97]. 
En esta parte aparece Ujo, un enano extraído del viejo realismo español y de la novela picaresca, el «más feo, deforme y ridículo enano que es posible imaginar [...] y en todas las casas era objeto de chacota y befa» [Pérez Galdós, 2016: 199]. Al igual que en la novela, Ujo se enamora de Ándara y se producen escenas de seducción y cortejo entre dos seres marginales. Ujo intenta conquistarla ofreciéndole frutas, que en su mundo excluido remite a connotaciones religiosas: «cuando recibe la manzana de un paraíso perdido, que le entrega el enano» [Fuentes, 1988: 34]. Además, Ujo basa su amor en todo aquello que excluye a Ándara de la posibilidad de ser amada: «Eres fea, Ándara; eres pública, pero yo te estimo, yo te estimo Ándara» [Alejandro y Buñuel, 1989: 106]. La paradójica y hermosa historia de amor concluye abruptamente cuando los peregrinos son apresados y Ándara patea al enano que ha ido a prevenirles -en la novela le esputa con saña-. Ujo no podrá seguir a los presos ya que la deformidad de sus piernas no se lo permite, circunstancia que amplifica la maestría del encuadre y la profundidad de campo de Gabriel Figueroa. Cualquier posibilidad de redención queda aniquilada.

También es reseñable la retirada al monte de Nazarín con sus discípulas a las que previene de las tentaciones de la carne. En este sentido se producen los celos entre ellas. La película recrea una imagen en la que Beatriz pone su cabeza en el hombro del sacerdote sugiriendo una relación sexual: «Beatriz dejó gravitar su cabeza sobre el hombro de Nazarín, y se quedó dormidita, como un niño en el seno de su madre» [Pérez Galdós, 2016: 213]. El santo no la rechaza, ya que se recrea ensimismado en la contemplación de un caracol, espacio de su misticismo y escape de las problemáticas de este mundo, en el que se subraya que el sacerdote está lejos de cualquier veleidad amorosa ni siquiera en el área espiritual de la mujer. La imagen reaparecerá al final del filme, cuando Beatriz repita el mismo gesto en el hombro de Pinto, su maltratador. Carlos Fuentes considera que el secreto de la película era su erotismo subterráneo en el que las mujeres «no permiten que Nazarín las ideali- 
ce, sino que lo seducen y perturban. Lo demonizan en el acto de sus amores con un enano y un criminal. Don Quijote como testigo de los amores monstruosos y patibularios de sus Dulcineas» [2017: 86].

\section{UN IMPROVISADO FINAL ABIERTO Y AMBIGUO}

La última parte de la película concentra el viaje de Nazarín y Ándara con el resto de los presos, el maltrato que sufre el cura, el retorno de Beatriz a la seguridad de la infelicidad previa con Pinto y la apertura semántica que compone el final del filme.

Buñuel recrearía otro de los pasajes de la novela en el que los presos no cejan de burlarse de Nazarín que sufre estoicamente las humillaciones. En la celda, la paciencia de Nazarín se acaba cuando sus compañeros no solo son irreverentes con él sino con la fe, a lo que el santo responde encolerizado [Pérez Galdós, 2016: 244]. Como en el resto de la narración, el llamado a la beatitud y a las enseñanzas cristianas son respondidos a golpes, que solo cejan cuando uno de los reos intercede por el indefenso cura. Cuando este le agradece su acción, se produce otro de los escenarios que anticipa la futura duda del padre en el que se constata su fracaso. El «buen ladrón» le replica ante el parlamento para que encauce su vida: «Yo hago el mal, usted hace el bien; pero, al fin y al cabo, su vida ¿de qué sirve? Usted de lado bueno, yo del malo. Ninguno de los dos servimos para nada» [Alejandro y Buñuel, 1989: 119].

En el último capítulo del libro, Nazarín se encuentra solo en el hospital delirando y en una alucinación febril Jesús se le aparece y le dice: «No puedes celebrar, no puedo estar contigo en cuerpo y sangre, y esta misa es figuración insana de tu mente. Descansa, que bien te lo mereces. Algo has hecho por mí. No estés descontento. Yo se que has de hacer mucho más» [Pérez Galdós, 2016: 279]. En este contexto, todas las desgracias que ha sufrido el padre encuentran un sentido. 
En la película el final es completamente distinto ya que Nazarín duda de su fe en la escena de la piña que añade el director. Separado de la «cuerda de asesinos, ladrones y apóstoles» [Pérez Galdós, 2016: 266] el antiguo sacerdote se dirige a la ciudad custodiado por un centinela y en un descanso una mujer que vende fruta (María Cecilia Leger) le pide que acepte la caridad de una piña. En un primer momento Nazarín la rechaza, pero rectifica -él, que siempre defendió la limosna- y la acepta dando las gracias a la mujer con un metafórico «que Dios se lo pague». El final de la película se concentra en Nazarín caminando con la piña que tampoco puede comer ya que necesita instrumentos para abrirlamientras su rostro se cubre de lágrimas. Como explicaba el director: «A Nazarín llega un momento en que le falla todo. Además, el mismo es contradictorio. [...] Nazarín falla, porque está rechazando lo que ha sido el principio de su vida, sus creencias y se va llorando» [Turrent y De la Colina, 1999: 105-106].

El estruendo metafísico de los tambores de Calanda, que se inicia con la duda del santo, abre la interpretación de uno de los finales más hermosos y enigmáticos de la historia del cine, que concluye con la proyección de la palabra fin con la i en forma de cruz. El significado de ese momento ha sido sometido a infinidad de interpretaciones. Incluso, se llegó a decir que Buñuel había vuelto al redil del catolicismo. A este respecto, el director, puntualizaba en una entrevista para el diario Le Monde el 16 de diciembre de 1959: «Me gusta Nazarín porque es un filme que me ha permitido expresar ciertas cosas que llevo en el corazón. Pero no creo haber renegado ni abjurado de nada. Gracias a Dios soy todavía ateo» [Alcalá, 1973: 140].

\section{CONCLUSIONES}

Luis Buñuel reconocía que Nazarín era una de sus películas preferidas. En su transcripción de la novela desarrolló los rasgos esenciales 
del personaje de Galdós adaptándolo a la época y recreando fielmente el libro si exceptuamos la sustitución de la celebración de la misa final por la escena de la limosna y el añadido de elementos como la huelga y el diálogo sadiano, en el que la mujer agonizante reclama a su amante y rechaza a Dios.

Nazarín fue el segundo gran éxito internacional de su época mexicana cuando ganó el Gran Premio Internacional de Cannes en 1959 que supuso su reconocimiento e iniciaría la fase de los grandes éxitos internacionales de los sesenta y setenta, la emancipación del sistema de producción mexicano y la consagración como uno de los grandes maestros de la historia del cine. Como en Los olvidados, compartía la influencia de la obra de Benito Pérez Galdós que se proyectará en el futuro en Viridiana y Tristana.

La obra de Buñuel arrancaba de la apropiación del relato ajeno que condensaba reconfigurando el original con un carácter independiente y definitorio respecto a la novela. Nazarín partía de una interpretación ambigua que no era católica ni anticatólica ya que el cura no quería convertir a nadie. Esa ambigüedad determinó que fuera candidata al Premio de la Oficina Católica de la Haya, que recibiera premios de entidades católicas y fuera denostada por algunos de los colegas vanguardistas y comunistas del director a los que les parecía incomprensible que se focalizara una película en la vida de un cura. Pese al furibundo ateísmo de Buñuel el filme está indizado por el Vaticano como uno de sus referentes cinematográficos.

¿Y Benito Pérez Galdós? Como señalaba irónicamente Rafael Alberti, era paradójico que uno de los directores más tremendistas del mundo fuera un ávido lector de Galdós [Aub, 1985: 295]. Como hemos demostrado, en su madurez el canario le dejó una huella indeleble. Buñuel, que se jactaba de pertenecer al pueblo más blasfemo y sacrílego de la tierra se definía por una de las frases que mencionaba cuando le inquirieron por Nazarín: «Gracias a Dios soy todavía ateo». En la novela de Galdós España sin rey (1907), un periodista 
concretaba a uno de los personajes de este modo: «Este es Suñer y Capdevilla, diputado federalista, y ateo él gracias a Dios» [Pérez Galdós, 1908: 117]. Como reconoce Arantxa Aguirre es simbólico que la máxima que identificaba a Buñuel fuera una frase escondida en una de las páginas de la monumental obra galdosiana. En las adaptaciones Galdós y Buñuel coinciden en una obra que reinterpreta y resignifica el mito galdosiano proyectándolo a través de la imagen cinematográfica que ha constituido la lengua franca del siglo XX.

\section{BIBLIOGRAFÍA}

AlCALÁ, Manuel (1973): Buñuel. Cine e ideología, Madrid, Edicusa.

Aguirre, Arantxa (2020): "Galdós por Buñuel», en Luis Buñuel, eds. J. Angulo y J. Fernández (San Sebastián, Donostia Kultura), 171-180. (2008): Galdós y Buñuel: Correspondencias. En Luis Buñuel (1900-1983)

Suspiros y películas (s.d.), Madrid, Universidad Complutense, Edición electrónica.

AuB, Max (1985): Conversaciones con Buñuel, Madrid, Aguilar.

ARANDA, J. F. (1970): Luis Buñuel. Biografía crítica, Lumen, Barcelona.

BANVILlE, John, Claude Lemagny, Jean-Claude. y Fuentes, Carlos (2008):

Manuel Álvarez Bravo, Barcelona, Lunwerg.

BARbachano, Carlos (2000): Luis Buñuel, Madrid, Alianza.

Bravo CASTILlo, Juan (2010): Grandes hitos de la historia de la novela euroamericana, Cátedra, Madrid.

BuÑuel, Luis y AlejANDRO, Julio (1989): «Nazarín», en Sette film, ed. F. Goffredo (Turín, Einaudi), 51-122.

BUÑUEL, Luis y CARRIÈRE, Jean-Claude (1989): «La via lattea», en Sette film. ed. F. Goffredo (Turín, Einaudi), 323-397. (1982): Mi último suspiro, Barcelona, Plaza y Janes.

CAMACHO, Enrique, PÉREZ BAZO, Javier y Rodríguez Blanco, Manuel (eds.) (2000): Buñuel 100 años. Es peligroso asomarse al interior, Madrid, Instituto Cervantes.

CANTINI, Alberto (1995): Luis Buñuel, Milán, Il Castoro.

CARRIÈRE, Jean-Claude (2011): Para matar el recuerdo. Memorias españolas, Barcelona, Lumen. 


\section{JUAN AGUSTÍN MANCEBO ROCA}

Castillo, David y SARDÁ, Marc (2007): Conversaciones con José «Pepín» Bello, Barcelona, Anagrama.

Evans, Jo y VIEJO, Breixo (2018): Luis Buñuel. Correspondencia escogida, Madrid, Cátedra.

FUENTES, Carlos (2017): Luis Buñuel o la mirada de la medusa (Un ensayo inconcluso), Madrid, Fundación Banco de Santander.

(1992): El espejo enterrado, México, Fondo de Cultura Económica.

Fuentes, Víctor. (2000): Los mundos de Luis Buñuel, Barcelona, Akal. http://www.cervantesvirtual.com/obra/la-literatura-en-el-cine-debunuel-/ [20-7-2021].

(1993): Buñuel en México, Teruel, Instituto de Estudios Turolenses.

(1986): «La literatura en el cine de Buñuel», en Actas del IX Congreso de la Asociación Internacional de Hispanistas, ed. S. Neumeister (Berlín, Vervuert), 237-243.

GASCA, Luis (ed.) (1989): El mundo secreto de Buñuel, Barcelona, CCCB.

GIBSON, Ian (2008): Luis Buñuel. La forja de un cineasta universal (1900-1938), Madrid, Aguilar.

GUBERN, Román (2020): Un cinéfilo en el Vaticano, Barcelona, Anagrama.

LEVIN, Elías (ed.) (1996): Gabriel Figueroa. De Los olvidados a Viridiana, México, FCE.

Hidalgo, Manuel (2019): El banquete de los genios. Un homenaje a Luis Buñuel, Barcelona, Península.

Huston, John (1998): Memorias, Madrid, Espasa.

JONES, Julie (2018): Más allá de la pantalla con Luis Buñuel, Zaragoza, Universidad de Zaragoza.

Krohn, Bill y Duncan, Paul (Ed.): Luis Buñuel. Quimera 1900-1983, Colonia, Taschen.

LeVIN, Elías (Ed.) (1996): Gabriel Figueroa y la pintura mexicana, México, Museo de Arte Carrillo Gil.

López Villegas, Manuel (1998): Sade y Buñuel. El maqués de Sade en la obra cinematográfica de Luis Buñuel, Zaragoza, Gobierno de Aragón.

Martínez Herranz, Amparo (2020): "Triunfar o hundirse», en Luis Buñuel, eds. J. Angulo y J. Fernández (San Sebastián, Donostia Kultura), 81-107.

Monegal, Antonio (1993): Luis Buñuel de la literatura al cine. Una poética del objeto, Madrid, Anthropos.

Monsiváis, Carlos (2006): Imágenes de la tradición viva, México, Fondo de Cultura Económica.

NAVARRETE, Ramón (2003): Galdós en el cine español, Madrid, T\&B. 
OrozCO, Héctor (2019): Nazarín, Manuel Álvarez Bravo- Luis Buñuel, Madrid, Fundación Televisa/PhotoEspaña.

PAZ, Octavio (2012): Luis Buñuel: El doble arco de la belleza y la rebeldía, México, Fondo de Cultura Económica.

Peña Ardid, C. y Lahuerta Guillén, V. (eds.) (2007): Los olvidados. Guion y documentos. Zaragoza, Gobierno de Aragón.

PÉrEZ GALDós, Benito (2018): La desheredada, Madrid, Alianza. (2016): Nazarín, Madrid, Alianza.

(2016): Halma, Sevilla, Alfar, Edición Kindle.

(2004): Tristana, Barcelona, La Galera.

(2003): Obras completas I, Madrid, Aguilar.

(1908): España sin rey, Madrid, Perlado, Páez y Compañía

http://www.cervantesvirtual.com/obra-visor/espana-sin-rey--

0/html/ff410310-82b1-11df-acc7-002185ce6064_2.html\#I_12_ [78-2021].

(1890): La Sombra; Celín; Tropiquillos; Theros, Madrid, LaGuirnalda. http://www.cervantesvirtual.com/obra-visor/la-sombra-celintropiquillos-theros--0/html/ff41a07c-82b1-11df-acc7-

002185ce6064_2.html [7-8-2021].

(1883): El doctor centeno, Madrid, La Guirnalda.

http:/ / www.cervantesvirtual.com/obra-visor/el-doctor-centeno--

0/html/ff1e5252-82b1-11df-acc7-002185ce6064_3.html [7-82021].

Pérez Turrent, Tomás y De La Colina, J. (1993): Buñuel por Buñuel, Madrid, Plot.

SÁNCHEZ VIDAL, Agustín (2009): "Transferencias», en Luis Buñuel y Salvador Dalí. Un perro andaluz ochenta años después, eds. Y. Hernández Pin y P. Sánchez (Madrid, La Fábrica), 73-94.

https://issuu.com/lafabrica/docs/un_perro_andaluz [20-7-2021].

(2000): El mundo de Luis Buñuel, Zaragoza, Caja de Ahorros de la Inmaculada.

(1982): Luis Buñuel. Obra literaria, Zaragoza, Heraldo de Aragón.

SinNIGEN, John H. (2008): Benito Pérez Galdós el cine mexicano: Literatura y cine, México, UNAM.

TUÑón, Julia (2013): «Buscando/saboteando los premios internacionales Nazarín vs. La cucaracha en el XII Festival de Cannes», Nueva Época, 13: 26-31.

https://mediateca.inah.gob.mx/repositorio/islandora/object/articulo:1 1566 [20-7-2021]. 


\section{JUAN AGUSTÍN MANCEBO ROCA}

SOLÍs, Fermín (2019): Buñuel en el laberinto de las tortugas, Barcelona, Reservoir Books.

VV. AA. (2004): Los olvidados. Una película de Luis Buñuel, México, Fundación Televisa.

\section{FILMOGRAFÍA}

BuÑueL, Luis (Dir.) (1972): Tristana [Largometraje], Divisa.

(Dir.) (1969): La Vía Láctea [Largometraje], Universal.

_ (Dir.) (1965): Simón del desierto [Largometraje], Mercury.

_ (Dir.) (1958): Nazarín [Largometraje], Divisa.

_ (Dir.) (1955): Ensayo de un crimen [Largometraje], Divisa.

_ (Dir.) (1953): El Bruto [Largometraje], Cameo.

_ (Dir.) (1950): Los olvidados [Largometraje], Televisa.

_ (Dir.) (1949): El gran calavera [Largometraje], DeAPlaneta.

_ (Dir.) (1945): Gran Casino [Largometraje], Manga Films.

_ _ (Dir.) (1933): Las Hurdes. Tierra sin pan [Largometraje], Scerén.

_ (Dir.) (1930): La edad de oro [Largometraje], Llamentol.

(Dir.) (1928): Un perro andaluz [Cortometraje], Filmoteca Española.

ESPADA, Javier (Dir.) (2018): Buñuel en el laberinto de las tortugas [Largometraje], Sygnatia/The Glow/Submarine.

_ (Dir.) (2015): Tras Nazarín. El eco de una tierra en otra tierra [Documental], Tolocha Producciones.

FERNÁNDEZ, Emilio (Dir.) (1950): Un día de vida. [Largometraje], Cabrera Films

_ (Dir.) (1948): Pueblerina [Largometraje], Ultramar.

_ (Dir.) (1947): Río Escondido [Largometraje], Ventura.

Galindo, Alejandro (Dir.) (1951): Doña Perfecta [Largometraje], Vanguard Cinema.

RiOYO, Javier (Dir.) (1999): A propósito de Buñuel [Documental], Cero en conducta Producciones S. L.

RODRÍGUEZ, Ismael (Dir.) (1958): La cucaracha [Largometraje], Mart.

SAURA, Carlos (Dir.) (2001): Buñuel y la mesa del rey Salomón [Largometraje], Rioja Films. 
TORRES, Augusto (Dir.) (2002): Arturo Ripstein habla de Luis Buñuel [Documental], Cinema X y Z.

URRESTI, Gaizka y ESPADA, Javier (Dir.) (2008): El último guion. Luis Buñuel en la memoria [Documental], Aragón TV, Inmal, IMCINE, U de G, ZDF. 